\title{
第41回日本老年医学会学術集会記録 〈教育講演〉
}

\section{介護保険}

\author{
井口 昭久
}

Key words : 高齢者介護, 歴史的経緯, 社会保障制度, 老年科医の役割, 老年症候群

(日老医誌 $1999 ； 36 ： 699-702$ )

\section{はじめに}

「介護保険制度」が実施される2000年 4 月まで，残す ところ僅かとなった．介護保険受給のための各市町村へ の申請は, さらに 6 カ月早い1999年の10月からであり, 高齢者介護の現場は多忙を極めている.間近に迫った「介 護保険制度」について，述べていくことにする.

（1）高齢者介護に関する歴史的経緯について

我が国の高齢者介護の歴史をふりかえる場合，国家と しての老人保健福祉政策の経緯, および我が国の高齢化 の進展状況を参考に概観すると，その理解を助ける.

戦後の高齢者介護に関する政策的な介入は，1960年代 に入ってから始まる，それ以前の高齢者介護は，長期介 護が必要な高齢者の数が少なかったこともあり,「生活保 護制度」としての養老院が設けられることで対応されて きた．高齢化率が5.7\%となった1960年以降，老人医療 および老人福祉制度の基盤作りが行なわれることになっ たのである．1961年には医療保険が国民皆保険制度とな り，医療機関に対するアクセスが飛躍的に改善された。 またそのことによって，医療機関の増加による医療サー ビスの供給量増加の流れがもたらされた。 そして1963年 には老人福祉法の制定により, 特別養護老人ホームが開 設された。現在の医療・福祉サービスの原点となってい る制度が始まったのが1960年代と言えるであろう.

1970年代に入ると, 老人医療費の増加が大きな問題と なってくる.1961年に始まった医療保険であるが，当初 は被保険者の家族の自己負担率は 5 割であったため，高 齢者の受診率は緩やかな上昇を示していた，ところが 1973年に老人医療費の無料化が決定されると，その受診 率が飛躍的に上昇し, また受診率の増加に伴い医療サー ビス供給量が著しく増加したため, 老人医療費の高騰が 問題となったのである.ちなみに1970年の高齢化率は7.1 \%であった。

Public Long-term Care Insurance

Akihisa Iguchi : 名古屋大学大学院医学研究科老年医学 教室
問題となった老人医療費の増加に対応するため, 1980 年代には老人保健制度が創設されることになった。まず 1983年に老人保健法が成立した.この法律の制定により， 拠出金制度，および高齢者の医療費の一部自己負担が導 入されることになった. 支払い基金側の改善により増加 する老人医療費の財源を確保し, 自己負担を課すことで 収入の増加，および医療費増加の抑制を図ったわけであ る. また1986年には老人保健法が改正され, 老人保健施 設が新しく創設された。

1990年には高齢化率は $12.0 \%$ となり，高齢化社会の到 来が現実の問題となってきた．この前の年の1989年に高 齢者保健福祉推進10力年計画, いわゆるゴールドプラン が策定され，1990年代前半の高齢化社会に向けての基盤 作りの方針が示された．施設介護，在宅介護のサービス 量拡充が，まずそこでの目標となったのである.1990年 に入って, 福祉 8 法の改正が行われ, 福祉サービスの市 町村への一元化が実施された。この改正により，各市町 村に福祉サービスの運営が任され，地域のニーズに素早 く適応したサービスを提供することが期待された. 1991 年には再度老人保健法の改正が行われ，老人訪問看護制 度が創設された.また1992年には医療法の改正が行われ， 療養型病床群が創設されることになった。この年に介護 保険施設, つまり「特別養護老人ホーム」, 「老人保健施 設」,「療養型病床群」の三つの施設が制度化され, 施設 介護の枠組みが完成した.ゴールドプランはそのサービ ス供給量の目標值が上方修正され，1994年新ゴールドプ ランの策定となった.

1995年からは老人保健福祉審議会での介護保険制度に 関する検討が本格化し，1996年 5 月の通常国会への法案 提出は一度見送られたが，1996年の11月，臨時国会に介 護保険制度法案が提出された。そして1997年12月 9 日， 衆議院で二力所の法案修正と十六の付帯決議, 参議院で 一力所の修正と十九の付帯決議, 加えて一部の野党が欠 席したままの本会議採決という難産の末, 介護保険法が 臨時国会で成立となり, 現在に至っているのである.

1960年代より1997年の介護保険法案成立までの，約40 
表 1 日本の社会保障制度について

\footnotetext{
・公的扶助：最低限度の生活水準を維持するだけの所得や資産のない人々に，その不 足分だけを給付する制度. 生活・教育・住宅・医療・出産・生業・葬祭に扶助. 費 用は租税で賄う

·社会保険：疾病・老齢・失業・労働災害などに際して，現金やサービスを提供．費 用は主として事業主や本人の保険料で賄い，一部を租税で賄う

・社会福祉：児童・老人・身体障害者などの福祉の向上のために，施設やサービスを 提供. 費用は租税で賄い, 地方公共団体がサービスを提供

・公衆衛生：生活環境の整備や予防衛生によって, 国民の健康の維持・増進をはかる ことが目的. 費用は租税で賄う
}

年間の高齢者介護に関する歴史的な経緯を概説してきた が，ここで明らかになったのは，高龄者介護制度の歴史 はそう長いものでないということである．高齢者の介護 問題が国民的な関心を集め出したのは1990年代に入って からのことであり, 高齢化率の上昇, つまり高齢化社会 の到来とともに, 重要課題になった分野であるといえる.

（2）介護をめぐる「医療」と「福祉」の関係について 次に高齢者介護をめぐる「医療」と「福祉」の関係に ついて述べていくことにする.「医療」と「福祉」の関係 を述べるにあたって，まずはその前提に立つ日本の社会 保障制度について触れていきたい. 教科書的には, 日本 の社会保障制度については，四つに分類して説明されて いる ${ }^{1)}($ 表 1$)$ ，我が国の社会保障制度を参考にして，介 護に扔ける医療サービスから述べていくことにする.

高齢者介護における医療サービスであるが，これは社 会保障制度の中で「社会保険」として位置付けられる。 基本的に医療サービスは医療保険を利用した自由契約に よるサービスの提供といった形を取る．1961年の国民皆 保険制度，1973年の老人医療費の無料化，そして1983年 の老人保健法の制定などにより，広く国民の間に浸透し ていったという経緯が存在する．医療サービスはある程 度の「営利性」が存在しており，これがさらにサービス 供給量を増加させる要因ともなったともいわれてい $る^{2)}$. 具体的には, (1) 老人病院, 療養型病床群, 老人保 健施設での施設介護サービス, (2) 老人保健施設での短 期入所介護サービス，(3) 施設における通所介護サービ ス, (4) 訪問診療サービス, (5) 訪問看護サービス等が存 在する. 介護保険制度の実施後は, これらのサービスは 介護保険によってカバーされることになる．

次に高齢者介護における福祉サービスであるが，これ は社会保障制度の中で「社会福祉」として位置付けられ ている. そのサービス提供までの形態は, 行政が判断し た必要性,つまり身体障害の認定に基づいてとられる「措 置行為」である.このことは利用者とサービス提供者と の間に,「契約」という概念が存在していないことを意味 している.1963年の老人福祉法の制定，1990年の福祉 8 法改正などにより，サービス提供に対する改善が図られ
てきた．福祉サービスの財源はその殆どが国庫であり， サービス提供量の調整が行政によって管理されている. 具体的なサービスとしては（1）特別養護老人ホームで の施設介護サービス，(2) 施設での通所介護サービス，

（3）ホームヘルパーの派遣, 訪問入浴サービスなどの訪 問介護サービス, (4) 在宅介護支援センターなどでの相 談事業等が存在し，これらも介護保険によってカバーさ れることになる.

ここまで述べてきたように，本来同じであるはずの高 齢者介護をめぐり,「医療」と「福祉」はそれぞれ異なっ た経緯をたどりながら，そのサービスを提供してきた。 それが「医療」と「福祉」の連携をやや困難にしている のかもしれない. 連携をめぐる具体的な問題としては, まずサービス提供にいたるまでの過程が，まったく異 なっていることが挙げられる。保険証を持っていけば, 原則として誰でも利用できる医療サービスと異なり，福 祉サービスは役所に申請し, 措置が決定するまでの一定 期間必ず待機期間が存在する。そして措置行為によって サービスを利用することと, 自由契約によってサービス 利用することとでは, 利用者とサービス提供者との関係 が大きく異なる．勿論現在の医療サービスがすべて自由 契約であるかについては，大いに異論のあるところであ ろう。しかし原則的には, 大きな違いが存在する。また サービスの提供量に著しく格差が存在することも連携を 困難にする一因となっている，現在，福祉サービスの利 用にかなりの制限があるのは，よく経験されることであ る．また今までに双方の間で人的交流があまりなかった ために, 連携に不可欠なコミュニケーションが不足して いるという事実が存在する.このことは案外大きな問題 かもしれない.

次いで少し視点を変えて, 連携を困難ならしめる要因 を考えてみると次の 2 点があげられるであろう.まず「医 療」と「看護」と「介護」の定義が必ずしも明確ではな く, サービスの内容にも相当の重複が存在するというこ とである. そして, 高齢者長期ケアに関する共通の概念, また共通の言語がまだ確立しておらず, 理解を同じくし てなかなか議論できないことが問題と考えられる゙. 
このように高齢者介護をめぐって様々な問題が存在し ている現在の我が国ではあるが, 介護保険制度はそのよ うな我が国の高齢者介護の現状の中から，その必要性に 後押しされるよう浮上してきたともいえる。

（3）介護保険が必要となった背景について

次に介護保険が必要となった背景について述べてい く.その背景には大きく 3 つの不安や関心の増大がある.

1）高齢化の急速な進展（高齢化率は, 1960年には5.7 \%であったが，1980年には9.1\%，そして1995年には 14.5 \%になる)

高齢化の進展は欧米諸国のそれとは異なり，本当に急 速なものであったため, それに対する備えがまだ十分で ないことが問題である.

2）要介護高齢者の増加や介護期間の長期化, 介護内 容の重度化の進展

いわゆる Old old の増加も著しく, 介護負担度の高い 要介護高齢者が急増している.

3）家族機能の変容による（例えば核家族化の進展, 女性就労の増加など), 家族介護の困難化

家族介護に頼っていたのでは，女性の社会進出の妨げ にもなりかねない，介護の社会化がどうしても必要と なった大きな理由の一つである.

また高齢者介護に関する現行制度の問題点が，新しい 制度の創設を必要とした背景にある，具体的には，先ほ どからも関連事項について述べてきているが,

1）利用者である高齢者本人やその家族にとって, 現 行の仕組みでは介護サービスが利用しにくいこと

2）高齢者が利用できる介護サービスが，量的にも質 的にも不十分であること

3）介護ニーズを，実態として医療サービスがカバー しているため，介護に関する費用が医療保険で賄われて いること

といったことも介護保険制度の創設が議論になった理由 である。

（4）介護保険制度の特徵について

制度の実際は様々な書物で紹介されているので，その 内容についてはここでは他に譲るとして, 制度の特徵を 簡単に紹介することにする，我が国の介護保険制度は大 きく分けて次の三つの特色があると考えられる.

1）高齢者介護に対する社会的支援体制の構築（いわ ゆる介護の社会化)

社会的支援体制の構築によって, 安定した介護サービ スの供給を実現する可能性が存在すること

2）利用者本位のサービス体系の確立

利用者にとって利用しやすいサービス供給体制が実現 する可能性が存在すること

3）社会連帯による介護費用の確保(利用者によるサー
ビスの選択の保証やサービス受給の権利性の確保という 点で優れた,「社会保険方式」の導入)

サービス供給に必要な財源を安定させることが可能で あること

以上のような特徵が挙げられる。

（5）他国の介護保険制度との比較（ドイツおよびオラ ンダとの比較) について

それでは他国の介護保険制度と比較した場合, 我が国 の介護保険制度がどのような違いを有しているのかを検 証していく，現在国家として介護保険制度を実施してい るのはドイッ, そしてやや形態は異なるがオランダを挙 げることができる．まずこれらの国々の制度を簡単に説 明していくことにする.

まずドイツの介護保険制度であるが4,

1）保険者は現行の公的医療保険の保険者（職域また は地域を基盤とする8つの疾病金庫）が兼ねている

2）被保険者は公的医療保険加入者（全人口の約 $90 \%$ )

3）保険科（1）: 被用者については労使折半であり, 年金受給者については年金保険者と折半

4）保険料（2）: 被保険者の収入の $1.7 \%$ （ちなみに医 療保険率は平均 $13 \%$ 程度, また最高限度額は旧西ドイッ 地域が102マルク，旧東ドイツ地域が86.7マルク）

5）施設給付：月額2,800マルク．ただし末期癌患者な

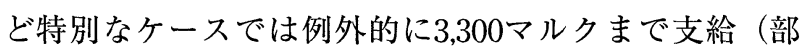
屋代や食事代は自己負担）される.

6）在宅給付：現物/現金給付のいずれかを選択. 現物 給付は月額 750 マルクから 3,750 マルクまでの 4 段階. 現 金給付は月額400マルクから1,300マルクの 4 段階.

次にオランダの介護保険について概説していくと 5 ,

1）オランダの医療保険には，カバーされるサービス の種類に応じて二つの制度が存在する．短期の医療費を カバーする短期医療保険と, 長期の治療・療養をカバー する特別医療保険があり，「介護保険」にあたるのは特別 医療保険である。

2）保険者：政府（疾病基金保険，私的保険，公務員 保険が業務を代行)

3）被保険者：オランダ在住者（国籍, 所得の夏多, 雇用状況を問わず)

4）保険料 : $9.6 \%$, 上限約 4,530 ギルダー（1998）

5）財源：保険料および一般財源（公費による補助）

6）カバーされるサービス：(1) 1 年以上の入院医療,

(2) ナーシングホームでのケア, (3) ナーシングホーム でのデイケア，(4) 訪問看護団体による在宅ケア，(5) 初 日からの精神病院での入院医療等

7）支払方法：業務を代行する各保険者への償還払い （1995年より現金給付が開始された）

以上ドイツとオランダの介護保険について紹介した 
表 2 我が国とドイツとの主な相違点

\begin{tabular}{|c|c|c|}
\hline & 日本 & ドイツ \\
\hline 給付対象 & $\begin{array}{l}65 \text { 歳以上の高齢者および } 40 \text { 歳以上の } \\
\text { 徒な疾患に罹患している老者 }\end{array}$ & 全年齢層 \\
\hline 財源 & 5 割保険料 $\cdot 5$ 割租税 & 全額保険料 \\
\hline 保険料 & 定額制 & 定率制 \\
\hline 要介護認定機関 & $\begin{array}{l}\text { 保険者である自治体に委託された要介 } \\
\text { 護認定審査会 }\end{array}$ & $\begin{array}{l}8 \text { 法定疾病金庫のために要介護認定を } \\
\text { 行ってきた者機関である MDK }\end{array}$ \\
\hline 訪問調査員 & $\begin{array}{l}\text { 保険者の職員か, あるいは保険者から } \\
\text { 委託された護支援専門員 }\end{array}$ & $\begin{array}{l}\text { MDK の認定されたメンバー（その大半 } \\
\text { は医師） }\end{array}$ \\
\hline 介護等級数 & 要支援 · 要介護度含めて 6 等級 & 4 等級 \\
\hline 現金給付の有無 & なし & あり \\
\hline
\end{tabular}

が，我が国とドイツの介護保険制度にはどのような違い が存在するのであろうか. 2 力国の相違点を比較してみ ると（表 2 ), 我が国とドイッの介護保険制度には相違

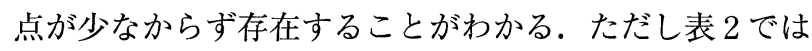
現金給付は我が国の場合なしと紹介してあるが，現金給 付が条件付きで実施されるとの報道も散見する．介護保 険制度はなおも流動的な要素を抱えているといえるであ ろう。

（6）介護保険制度における老年科医師の役割について さて介護保険について簡単に述べてきたところで, そ れではその新しい制度が実施された場合に，我々老年医 療に携わる医師がどのような役割を果たしていかなけれ ばならないのであろうか. 求められる役割は決して少な くないと考えられる。具体的には，

1）要介護度の認定において意見を求められる存在と して

介護認定審査会の一員として, 申請者の要介護度の最 終決定に関わる.

2）介護支援専門員として，あるいはその指導者とし $\tau$

3）介護保険施設等で高齢者を診察する医師として そして,

4）在宅介護サービスの供給機関の指導者として 重要な役割が期待されている.さらに要介護認定の際に 必要な「主治医の意見書」を作成する機会が多いに増え ることが予想される.「主治医の意見書」は，患者の要介 護認定の際, 重要な参考書類として利用されるので, 正 確に書くことは勿論, 作成する数がかなり多くなること が考えられる．記入に慣れて迅速に作成することも重要 だと思われる。

（7）介護保険制度の今後の課題について
最後に, 介護保険制度の今後の課題について言及する. 今後の課題といっても，多角的に捉えると様々なものが 存在する.

1）情報公開とサービスの質の確保

介護保険制度で普及すると思われるケアマネジメント の実施には, 情報公開は不可欠である. 高齢者のニーズ に応じた，介護サービスの質の確保は言うまでもない．

2）介護サービスネットワーク構築の必要性

ケアマネジメントの実施には, サービス提供機関の相 互のネットワークが重要である.

3）医療・福祉・保健の連携

4）高齢者介護の概念の構築

5）高齢者医療・看護・介護における共通言語の必要 性

共通言語の必要性ということにおいては，最近「老年 症候群」という概念が提唱されてきており ${ }^{6}$, 「長期ケア」 の概念とともに，医療・福祉・保健の概念を促進する新 しい考え方として，注目すべき概念である．

\section{文献}

1）岡本祐三：医療と福祉の新時代, 日本評論社, 東京, 1996.

2）広井良則：医療の経済学, 日本経済新聞社, 東京, 1996.

3）池上直己：医学・医療の新たな課題. 介護保険と高齢者 医療, 日本医師会雑誌臨時增刊 1997; Vol. 118, No. 9: 32-37.

4）本沢巳代子：公的介護保険一ドイツの先例に学ぶ, 日本 評論社, 東京, 1996 .

5）大森正博：オランダの医療・介護制度改革. 海外社会保 障情報 $1998 ; 124: 28$-44.

6）折茂 肇：21世紀の老人医療のあり方とその将来展望. Geriatric Medicine 1999;37:333-337. 